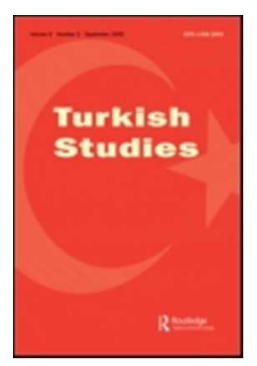

\title{
Europeanization of Civil Society in Turkey: Legacy of the \#Occupygezi Movement
}

\begin{tabular}{|r|l|}
\hline Journal: & Turkish Studies \\
\hline Manuscript ID & Draft \\
\hline Manuscript Type: & Original Article \\
\hline Keywords: & $\begin{array}{l}\text { Occupygezi, Europeanization, Turkey, social movements, Critical } \\
\text { Europeanism }\end{array}$ \\
\hline \multicolumn{2}{|l}{} \\
\hline
\end{tabular}

SCHOLARONE $^{\text {"x }}$

Manuscripts 


\title{
Europeanization of Civil Society in Turkey: Legacy of the \#Occupygezi Movement
}

\begin{abstract}
The Occupygezi movement has revealed that a more comprehensive approach needs to be taken in order to understand the deep socio-political drives underpinning the Turkish bid for EU membership. Focusing on three different framings, namely Euro-enthusiastic, Euro-skeptic and critical Europeanist frames, developed by the civil society organizations in Turkey since the 1999 Helsinki Summit of the European Union, this article will show the transformative effect of the Occupygezi movement on the mindsets of secular groups, who were previously Euro-skeptic. Subsequently, the article will claim that the last frame is recently becoming stronger along with the authoritarianization of the Turkish state. Methodologically, the paper will be based on the literature survey of civil society actors, and discourse analysis of the civil society actors (associations, trade unions, and the media) in relation to their changing perception of the EU before and after the Occupygezi movement.
\end{abstract}

Keywords: Occupygezi, Europeanization, Euroskepticism, critical Europeanism, civil society, Turkey

\section{Introduction}

The aim of this article is to examine the relationship between the European Union and Turkey from the specific angle of the process of Europeanization, a process which facilitated the mobilization of Turkish civil society actors during and after the \#Occupygezi movement in the summer of 2013. The author assumes that a more comprehensive approach needs to be taken in order to understand the deep socio-political drives underpinning the Turkish bid for EU membership as economic or geopolitical arguments do not exhaust the debate on Turkey's EU accession. From this perspective, understanding the broader process of Europeanization in political and social terms is crucial in order to capture the real drives of the European integration process in its entirety.

This article focuses specifically on three different framings developed by the civil society organizations (CSOs) in Turkey with respect to the European integration process, which is believed to have deepened since the 1999 Helsinki Summit of the European Union. These three main frames are Euro-enthusiastic, Euro-skeptic and critical Europeanist attitudes generated by different civil society actors as a response to the changing political, social, economic and cultural climate between Turkey and the European Union as well as within Turkey itself. Theoretically speaking, the Euroenthusiastic frame proposes a positive assessment of European development and detects some problems in the implementation of the project, which are believed to be resulting from the EU institutions. The Euro-skeptic frame tends to read the regional integration process as a set of detrimental dynamics that threatens the communitarian bases necessary for the sustainability of the local and national political projects. This frame is a more local and nationalist interpretation of European integration, which is perceived as a direct intervention in the sovereignty of the nationstates. The critical Europeanist frame searches for a more social and democratic Europe rather than a market-based Europe. As will be further delineated, this last frame was developed during and after the Gezi movement, which spilled over to the entire country in June 2013 as a popular form of resistance against the authoritarian rule of the Justice and Development Party, which has governed the country since 2002. It will be argued that it was this last form of framing that has made at least some Turkish civil society actors embrace the European integration process as an anchor for the democratization of the country. ${ }^{1}$ Focusing on three different framings developed by civil society 
organizations in Turkey since the 1999 Helsinki Summit, this article will show the transformative effect of the \#Occupygezi movement on the mindsets of secular groups, who were previously Euroskeptic. Subsequently, the article will claim that the last frame, the critical-Europeanist frame, has recently being challenged by the refugee deal made between the EU and the Turkish state in March 2016, due to the belief of the critical Europeanist individuals and groups that the EU has prioritized security concerns over the European values. Methodologically, the article is based on the literature survey, qualitative field research on the civil society actors, and discourse analysis of the civil society actors (associations, trade unions, and the media) in relation to their changing perception of the EU.

\section{The competing frames in the Turkish discourse on Europe}

In this section, different types of Euro-framings generated by Turkish CSOs will be delineated to see to what extent Turkish civil society has internalized and/or externalized the wider Europeanization trend. In this regard, three different forms of framing will be introduced: a) Euroenthusiastic attitudes; b) Euro-skeptic attitudes; and c) critical Europeanist attitudes. However, the focus will be on the last frame as the first two frames have so far been extensively discussed in the European studies literature and elsewhere. Kaya and Marchetti already stated that there are three main frames which could be distinguished in the current debate among European civil society actors. $^{2}$ The predominant frame, at least before the eruption of the 2008 financial crisis, for the political action of many civil society actors, is the Euro-enthusiastic attitude. Despite entailing different degrees of support for the European project, the Euro-enthusiastic frame proposes a positive assessment of the European development so far, and more importantly detects the actual origin of the current problems of the EU institutions. Euro-skepticism as a frame suggests a reading of the regional integration process as a set of detrimental dynamics that threatens the communitarian bases necessary for the sustainability of the local and national political projects. This frame has recently become very popular among the private European citizens who suffer from the devastating effects of the neo-liberal governance leading to the isolation and alienation of the rural, less educated, unemployed and elderly individuals. Finally, a third growing frame is represented by the critical Europeanists. According to this, a social Europe should be strengthened in opposition to the Europe of markets. A more political Europe, it holds, is needed to counter the apolitical and elitedriven Europe that we have known so far. The process of Europeanization is seen from this angle as developing also by contestation: a contested public debate is the surest path towards supranational legitimacy.

The European Union perspective offered in Helsinki has radically transformed the political establishment in Turkey, opening up new prospects for various ethnic, religious, social and political groups in Turkish civil society. Kurds, Alevis, Islamists, Circassians, Armenians and a number of religious and ethnic groups in Turkey have become true advocates of the European Union in a way that has affirmed the pillars of the political union as a project for peace and integration. The normative and transformative power of the EU provided immediately after 1999 a great incentive and motivation for numerous groups in Turkey to reinforce their willingness to coexist in harmony. What lies beneath this willingness no longer seems to be the glorious retrospective past, which has lately been perceived to be full of ideological and political disagreements among various groups, but rather the prospective future, in which ethnic, religious and cultural differences are expected to be embraced in a democratic way. ${ }^{3}$ The EU has thus appeared to be the major catalyst in accelerating the process of democratization in Turkey, or in other words, a lighthouse illuminating Turkey's road to modernization and liberalization. ${ }^{4}$ However, this kind of Euro-enthusiastic frame was later challenged by different groups on various grounds.

In the Turkish debate on Europe, there have been moments and dimensions critical of the EU. From $17^{\text {th }}$ December 2004 to $3^{\text {rd }}$ October 2005, when EU state and national government leaders decided to start negotiations with Turkey, tensions began to rise between nationalist, patriotic, 
statist, pro-status-quo groups on the one hand and pro-EU groups on the other hand. This was the time when the virtuous cycle of the period between 1999 and 2005 was replaced by the vicious cycle starting in late 2005. A new nationalist and religious wave embraced the country, especially among middle class and upper middle class groups. The actual start of the accession negotiations in 2005 was a turning point towards Euro-skepticism. This was also observed in several previous cases during the accession negotiations of the 2004/2007 entrants. The political elite and the government had come to realize that accession negotiations are not in fact "negotiations" but rather a unilateral imposition from the EU. ${ }^{5}$ Furthermore, this reality of actual accession negotiations is often abused by politicians to unfoundedly blame many governmental actions on the EU. Whether the "blaming of Brussels" is honest or not, the overall impact on public support has almost surely been negative. The electoral cycle of presidential and general elections witnessed militarist, nationalist and Euroskeptic aspirations coupled with rising violence and terror in the country prior to the elections in 2007. The fight between the Justice and Development Party (AKP) and the other statist political parties, backed by the military establishment, became crystallized during the presidential election in May 2007. The AKP gained an absolute majority of parliamentary seats in the 2002, 2007, 2011 and 2015 general elections, as well as in the 2004, 2009 and 2014 local elections. It became the first party since 1987 to win the majority of seats in the Turkish parliament. ${ }^{6}$

Euro-skepticism, nationalism and parochialism in Turkey were triggered by the sentiments of disapproval towards the American occupation of Iraq, the limitations on national sovereignty posed by the EU integration, the high tide of the 90th anniversary in 2005 of the Armenian "deportation"/"genocide" among the Armenian diaspora, the "risk of recognition" of southern Cyprus by Turkey for the sake of EU integration, anti-Turkey public opinion in the EU countries framed by conservative powers (e.g. France and Austria), and Israel's attacks on Lebanon in 2006. Against such a background, the state elite has also become very skeptical of the Europeanization process. The best way to explain the sources of such skepticism among the state elite is to refer to the "Sèvres Syndrome," which is based on a fear deriving from the post-World War I era and characterized by popular belief regarding the risk of the break-up of the Turkish state. ${ }^{7}$ AKP immediately stepped back after 2005 from its pro-European position, as it was perceived by the party that the EU no longer paid off. Actually, it was not the nationalist climax in the country that turned the AKP into a Euro-skeptic party, but rather the decision of the European Court of Human Rights vis-à-vis the headscarf case of Leyla Şahin v. Turkey, which challenged a Turkish law banning wearing the Islamic headscarf at universities and other educational and state institutions. ${ }^{8}$

The public frustration about the European stance on Turkey's membership and the associated Euro-skepticism reached high levels. The transatlantic trend survey of the German Marshall Fund undertaken in 2010 reveals this negative mood within the civil society. ${ }^{9}$ When asked for the relation between Turkey and the European Union, 35 percent of the Turkish public indicated a negative relation, 28 percent a mixed relation and only 22 percent a positive relation. When asked for the countries that Turkey should act in closest cooperation with on international affairs, the EU scored a substantial decline from 22 percent to 13 percent, and countries from the Middle East increased significantly between 2009 and 2010 from 10 to 20 percent. In the meantime, 34 percent argued that Turkey should act alone. Additionally, when asked for a general assessment of Turkish membership in the EU, while 73 percent of the Turkish public considered an EU membership a good thing in 2004, the rate had declined to 38 percent by 2010. Furthermore, while in 2004 only 9 percent considered EU membership a bad thing, 31 percent viewed it as undesirable in 2010. However, after the Occupygezi movement, which will be discussed in the following section, the support for European Union membership went up to 43 percent. ${ }^{10}$ The \#Occupygezi movement became the trigger for the emergence of a form of critical Europeanism. There appeared a sharp increase in public support for Turkey's membership to the EU following the Gezi movement, climbing up to 61 percent in 2015, and 75 percent in May 2016. The main driving force behind this growing public support for the EU was the increasing longing of the majority of the Turkish society 
for democracy, accountability, transparency, freedom of speech and the rule of law, the values of which the EU was strongly believed to have.

\section{Emerging Critical Europeanism in the Aftermath of \#Occupygezi}

Occupygezi is one of those new global social movements which has similar characteristics to its predecessors such as Tahrir Square, Occupy Wall Street and the European Indignado movement. The Gezi movement has become very instrumental in the sense that Turkish civil society actors have reframed European integration. Following the Gezi movement, Turkish civil society has become more pro-European, and the European Union circles have also changed their perceptions about the Turkish society. In the meantime, the main oppositional party, the Republican People's Party (CHP), has also become more pro-European after the Gezi movement. The leader of the CHP, Kemal Kilicdaroglu, even wrote a letter to the German Chancellor Angela Merkel urging her not to block Turkey's EU accession talks due to the brutality of the police forces against the protestors during the \#Occupygezi movement. ${ }^{11}$ It was very remarkable that the Gezi movement actually made the CHP as well as some previously Euro-skeptic civil society organizations like the labor unions (e.g. the Confederation of Progressive Trade Unions, or DISK) and certain oppositional newspapers, such as Sözcü and Cumhuriyet, become pro-European, or critical Europeanists. ${ }^{12}$ In a way, they have generated a more critical stance on Turkey-EU relations as they have become more in favor of a socially, democratically and politically prosperous European Union.

The Occupygezi movement also bears various characteristics similar to its predecessors such as Tahrir, Occupy Wall Street, and Indignado protests. Alain Badiou argued that Tahrir Square and all the activities which took place there, such as fighting, barricading, camping, debating, cooking, bartering and caring for the wounded, constituted the 'communism of movement' in a way that posited an alternative to the neoliberal democratic and authoritarian state. ${ }^{13}$ Similarly, Slavoj Žižek claimed that only these totally new political and social movements without hegemonic organizations and charismatic leaderships could create what he called the 'magic of Tahrir.'14 Hardt and Negri also joined them in arguing that the Arab Spring, Europe's indignado protests and Occupy Wall Street expressed the longing of the multitude for a 'real democracy' against corporate capitalism. ${ }^{15}$ The Occupygezi movement is similar to the others in the sense that it has brought about a prefigurative form of politics, as it symbolized the rejection in all walks of life of Erdogan's vanguardism and engineering of the life-worlds of Turkish citizens: raising 'religious and conservative youth', his call to mothers to have at least three children, his direct intervention in the content of Turkish soap operas, his direct order banning alcohol on university campuses, his intention to build mosques in Taksim Square and on Camlica Hill, his condescending say over the lives of individuals and his increasing authoritarian discourse, which is based in Islamic references. $^{16}$

As Marina Sitrin put it in the context of the Occupy Wall Street protests, the purpose of the Gezi movement was "not to determine the path the country should take, but to create the space for a conversation in which all can participate and determine together what the future should look like."17 Rejecting all kinds of hierarchies and embracing prefigurative politics, citizens of all kinds (youngsters, socialists, Muslims, nationalists, Kemalists, Kurds, Alevis, gays/lesbians, ecologists, football fans, hackers, artists, activists, academics, anarchists, anti-war activists, women's groups, and others) gathered in Gezi Park in Taksim. Gezi Park has in the past been a site for left-wing working-class demonstrations, to create a multiplicity of spaces such as social centers, graffiti walls, libraries, collective kitchens, music venues, conference venues, day care corners, book fairs, barter tables, utopic streets and squares ${ }^{18}$ and democratic forums, which provide room for experimentation, creativity, innovation and dissent. These civil utopias brought about a form of solidarity which is cross-cultural, cross-religion, cross-ethnicity, cross-class and cross-gender. Respecting difference was also embedded in these civil utopias, where practicing Muslims 
respected atheists, atheists respected practicing Muslims, all respected homosexuals, Kemalists respected the Kurdish activists, Kurds respected the Kemalists, Besiktas football fans respected Fenerbahce fans and the elderly respected the youngsters. In the spaces of communication created by the demonstrators, individual civil society actors coming from different ideological grounds had the chance to experience a form of deliberative democracy. In one of her works on the current social movements, Donatella Della Porta draws our attention to the critical trust generated by the demonstrators in such deliberative settings:

\begin{abstract}
By relating with each other, recognizing the others and being by them recognized, citizens would have the chance to understand the reasons of the others, assessing them against emerging standards of fairness. Communication not only allows for the development of better solutions, by allowing for carriers of different knowledge and expertise to interact, but it also changes the perception of one's own preferences, making participants less concerned with individual, material interests and more with collective goods. Critical trust would develop from encounter with the other in deliberative settings. ${ }^{19}$
\end{abstract}

The Gezi movement also provided its participants with an experience of direct democracy by which the holders of different points of view interact and reciprocally transform each other's views. ${ }^{20}$

As in Tahrir Square and Zucotti Park, the demonstrators of Gezi Park also made a point of keeping the park clean throughout the demonstrations to show the capacity of "the people" to govern themselves. ${ }^{21}$ The Occupygezi movement was also meant to be an attempt to reassemble the social sphere, which had been polarized in different spheres of life between the so-called secularists and the Islamists. It was revealed that most of the demonstrators had not been involved in any organized demonstration before. ${ }^{22}$ Gezi Park provided those youngsters who usually only communicate online with a meeting ground where they experienced communicating face to face. Against the segregation and isolation of everyday life, Occupy offered participatory structures and open communication. It invited passive citizens to experience an active sense of what James Hoslton calls 'insurgent citizenship' by which they could see what an inclusive and egalitarian society might look like. ${ }^{23}$ The Gezi movement was about creating alternative pathways for political organization and communication to prefigure the real democracy and active citizenery to come. The movement introduced millions of citizens all around the country to the experience of direct democracy. It radicalized an entire generation of previously discouraged and apathetic youth, and it built test zones for imagining and living out a post-capitalist utopia organized outside profit, competition and the corporate world.

Henri Lefebvre's path-breaking notion of "the right to the city" is probably the most meaningful theoretical intervention to be used to explain what the Occupygezi movement actually refers to. Lefebvre defines the city as "an oeuvre, a work in which all citizens participate." 24 Lefebvre does not accept the monopoly of the state in constructing the urban space. The city is a public space of interaction and exchange, and the right to the city enfranchises dwellers to participate in the use and reproduction of urban space. The right to the city is the right to "urban life, to renewed centrality, to places of encounter and exchange, to life rhythms and time uses, enabling the full and complete usage of ... moments and places." ${ }^{25}$ Similarly, David Harvey defines the right to the city as being "far more than a right of individual or group access to the resources that the city embodies: it is a right to change and reinvent the city more after our hearts' desire. It is, moreover, a collective rather than an individual right, since reinventing the city inevitably depends upon the exercise of a collective power over the processes of urbanization. The freedom to make and remake ourselves and our cities is one of the most precious yet most neglected of our human rights." 26

What happened in Gezi Park was a revolt of the masses against the everlasting authority of the state in shaping the public space as well as the city. The revolt was spontaneously organized by youngsters of every kind, who were mobilized through new social media like Twitter and Facebook. The choice of Gezi Park, which is located at the very center of the city, was also symbolically 
important, as it was meant to be the space restored from the hands of the corporate world collaborating with the neo-liberal state. Lefebvre finds the use of the city center by the dwellers of that city to be very important with regard to the materialization of the right to the city:

\begin{abstract}
The right to the city, complemented by the right to difference and the right to information, should modify, concretize and make more practical the rights of the citizen as an urban dweller (citadin) and user of multiple services. It would affirm, on the one hand, the right of users to make known their ideas on the space and time of their activities in the urban area; it would also cover the right to the use of the center, a privileged place, instead of being dispersed and stuck into ghettos for workers, immigrants, the 'marginal' and even for the 'privileged. ${ }^{27}$
\end{abstract}

Hence, the Occupygezi movement has become a civil-political venue in which youngsters of every kind have communicated with each other in a deliberative form and become active agents of civil society in a way that has proved the merits of the ongoing Europeanization processes. One should also not forget about the symbolic importance of Taksim Square, in the center of the city next to Gezi Park, which is very meaningful to secular segments of Turkish civil society. The historical Republican Monument (Cumhuriyet Aniti) symbolizing the Independence War and the foundation of the Turkish Republic, the Atatürk Cultural Center (Atatürk Kültür Merkezi) symbolizing Kemalist modernity, modern arts and music, and Taksim Square symbolizing the history of the working-class movements and May Day celebrations are all very important symbols of modernity, Westernization, secularization and Europeanization, terms which are likely to be used interchangeably by Turkish citizens. ${ }^{28}$

\title{
The Actors in the Turkish Public Debate on Europe
}

Europe and Europeanization are perceived very differently by various actors depending on the ways in which these two entities have been operationalized by the actors in question. Europe has been an important anchor for the democratization process of Turkey in the last two decades. Particularly in the aftermath of the Helsinki Summit of 1999, EU harmonization efforts to align Turkey's policies with those of Europe occupied the political agenda and led to various constitutional amendment packages. $^{29}$ However, while 1999-2005 marks the rapid reformation of the Turkish legal framework, 2005 marks the loss of momentum for said reformation process along the lines of the Copenhagen criteria. The EU anchor, which was considered to be at its strongest in the 1999-2005 period, hence its being considered the "virtuous cycle," yielded to the "vicious cycle," where the EU anchor weakened and the reformation process almost came to a halt. There are several different social and political actors shaping the Europeanization process of Turkey: civil society organizations, trade unions and the media. This section will elaborate on the perspectives of these actors on the EU before and after the Occupygezi movement. In doing so, the work shall mainly scrutinize the mainstream actors without touching upon the minor actors due to the space limitations of the work.

\section{Civil Society Organizations}

Regarding the nature of civil organizations in Turkey, an important argument was made by Keyman and İçduygu that the direction of Turkish modernization since the 1980s and the increasing participation of civil society actors in the policy-making process is a result of four processes. They are as follows: (1) the changing meaning of modernity, or in other words the emergence of alternative modernities, which refers to, first, the emergence of the critique of the status of secularrational thinking as the exclusive source of modernity in Turkey, and second, the increasing strength of Islamic discourse both as a 'political actor' and as a 'symbolic foundation' for identity formation; (2) the legitimacy crisis of the strong state tradition, which occurred as a result of the shift towards civil society and culture as new reference points in the language and terms of politics; (3) the process of European integration, referring to the assertion that reforms also indicate that the sources of democratization in Turkey are no longer only national but also global, and therefore that 
the EU plays an important role in the changing nature of state-society relations in Turkey, and functions as a powerful actor generating a transformative power in Turkish politics; and (4) the process of globalization in which Turkish politics functions as a significant external variable for understanding the current state of the political process in Turkey. ${ }^{30}$

Although Turkish civil society organizations have been deemed weak policy actors due to the assertion that respect for authority is stressed over citizen empowerment and participation while democracy has been shallow, imposed from above by Westernizing elites on a largely peasant, passive society, in the 1980s and particularly in the 1990s civil society organizations began to proliferate. ${ }^{31}$ While it is agreed upon that this proliferation was highly contingent on economic liberalization, Keyman and İçduygu argue that this increase can also be associated with the political parties, such that:

the center-Right and center-Left political parties have continuously been declining in terms of their popular support and their ability to produce effective and convincing policies, while at the same time both the resurgence of identity politics and civil society have become strong and influential actors of social and political change. ${ }^{32}$

Ersin Kalaycığlu agrees that although the visible statist orientation (étatism) in Turkey stresses community over the individual, uniformity over diversity and an understanding of law that privileges collective reason, the reasons for this phenomenon are founded on the critical relations between the center and the periphery. ${ }^{33}$

Perhaps as a part of this dynamic, namely the association of the center with the state, Kalaycıoğlu argues that, among others, TÜSİAD (Türk Sanayicileri ve İşadamları Derneği, Turkish Industrialists and Businessmen Association), Türk-İş (Türkiye İşçi Sendikaları Konfederasyonu, Confederation of Turkish Trade Unions), TOBB (Türkiye Odalar ve Borsalar Birliği, The Union of Chamber and Commodity Exchanges of Turkey), MÜSİAD (Müstakil Sanayici ve Işsadamları Derneği, Independent Industrialists and Businessmen Association), and TUSKON ((Turkey's Businessmen and Industrialists Confederation) often benefit from their cooperation with the state, rather than cooperation with other voluntary associations to pressure the state. As a rule, voluntary associations do not seem to consider the state as an adversary, but rather as an ally to be mobilized against their competitors. ${ }^{34}$ The corporatist path-dependent stance of the aforementioned associations has also recently continued upon the authoritarian rule of President Erdoğan. On the other hand, protest movements and advocacy associations which confront the Turkish state and advocate change in the political system are not received well by the state, though they receive media attention. ${ }^{35}$ In contrast, Atan argues that certain civil society organizations do not necessarily cooperate with the state and that

...while Turkish civil society is traditionally weak vis-à-vis the state, Turkish PBOs [Peak Business Organizations] appear as significant actors to challenge the government's policy agenda. Familiarisation with the EU-level governance system had provided them with additional resources to act upon the domestic agendasetting process. ${ }^{36}$

To that effect, it should be noted that TÜSİAD, an association including big business, has been one of the most discussed civil society actors in literature. In terms of EU membership, Atan argues that TÜSIAD played an important role in the aftermath of 1997 by strengthening their ties with their European counterparts through the EU institutions and governments in order to encourage Turkey's EU membership. ${ }^{37}$ Additionally, TÜSİAD prompted domestic policy changes in Turkey in favor of harmonization with the EU member states through the 1997 report entitled "The Perspectives on Democratization in Turkey." 38 These reports have been discussed and cited by several scholars as a reflection of the growing civil society participation in the domestic policy-making process.

MÜSİAD (Müstakil Sanayici ve İşadamlarl Derneği, Independent Industrialists and Businessmen Association) is another business association that mainly consists of AKP supporters. 
MÜSİAD appears to be an organization advocating a different model of economic and social development using a certain interpretation of Islam to ensure the cohesion of its members and to represent their economic interest as an integral component of an ideological mission. ${ }^{39}$ Consequently, MÜSİAD follows a discourse emphasizing the compatibility of EU membership with the 'Islamic and democratic identity' of the Turkish society, ${ }^{40}$ a discourse which is quite similar to the arguments made by the members of the AKP. On the other hand, the Europeanization process has produced two dynamics: firstly, economic Europeanization as a social learning process and political Europeanization as political opportunism, and secondly, an ongoing Euro-skepticism. ${ }^{41}$ Furthermore, one could also observe that there is an interesting shift from hard Euro-skepticism based on a civilizational divergence argument towards a soft Euro-skepticism expressed in national interest and in a new Islamic rhetoric in line with the assumption that Turkey has become a "soft power" in its region in the late 2000s. TUSKON (Turkey's Businessmen and Industrialists Confederation), another business association, was founded during the 1990s. The association consists of seven federations based on more than two hundred local associations and more than 55,000 entrepreneurs scattered all around the world. The most distinctive feature of TUSKON is its close ties with the Gülen Movement, which was an ally of Recep Tayyip Erdoğan until very recently. ${ }^{42}$

In addition to business associations, it should be noted that the IKV (Iktisadi Kalkınma Vakfi, Economic Development Foundation) was established as an initiative of the Istanbul Chamber of Commerce in 1965 to inform the public about the internal affairs of the EU as well as the relations between Turkey and the EU. Similarly, TESEV (Türkiye Ekonomik ve Sosyal Etüdler $V a k f$, Turkish Economic and Social Studies Foundation) is a non-governmental think tank focusing on social, political and economic policies in Turkey. Both IKV and TESEV have been very active in informing the public and the government on EU-related issues. ${ }^{43}$ One should also note that there have been several other civil society organizations such as environmental groups (WWF, Regional Environment Centre), human rights organizations (Helsinki Citizens Assembly, TÜSEV, Anadolu Kültür), women's rights organizations (KADER, KAGIDER), LGBT groups, and international foundations (Heinrich Böll Foundation, Friedrich Ebert Foundation, Open Society Foundation, British Council, etc.) advocating the EU in Turkey. ${ }^{44}$

During and after the Gezi movement, the position of the above-mentioned business organizations largely differed from each other. TÜSIAD continuously criticized the AKP government on the issues of abortion, women's rights, freedom of press and fundamental rights. However, the clientalist and corporatist nature of state and business relations in Turkey put pressure on the secular business circles to remain in alliance with the government. Despite the corporatist links with the state actors, most of the members of the TÜSIAD took a supportive role for the democratic rights of the protesters. Taking a critical Europeanist position in his statement, TÜSIAD's chairman touched upon the disproportionate intervention of police forces against protesters that prompted the small protest into a full blown reaction towards the government. ${ }^{45}$ On the other hand, TUSKON was silent during the Gezi process. After the then PM Erdoğan explicitly started to accuse the Gülen movement about the Gezi protests, the members of TUSKON took a new position. The association started to accuse the government as corrupt and oppressive in line with the Gezi protestors. ${ }^{46}$

\section{Trade Unions}

In comparison to the literature on civil society organizations and political parties, the literature on trade unions with respect to their role in the Europeanization of Turkey during the post-Helsinki period is rather limited. Nevertheless, it is possible to characterize the stances of trade unions as rather cautious and inconsistent. For instance, on the one hand they argue that the Europeanization process would cause unemployment and the disintegration of the country; on the other hand, EU 
membership is seen as providing an opportunity to move forward and to improve labor rights. ${ }^{47}$ However, it is also noted by others that:

Many of the labor market problems currently experienced in Turkey emerge in a context of rapid structural change. Until quite recently, the bulk of employment was in the agricultural sector, whereas today the urban labor force in industry and services is much larger than the rural workforce. ${ }^{48}$

In reference to her in-depth interviews with members of the labor unions, Zeynep Alemdar argues that although the literature expects them to appeal to the EU for better labor standards or workers' rights, Turkish domestic actors' use of the EU depends heavily on the domestic environment and their respective perceptions of the EU. ${ }^{49}$ In fact, Alemdar's argument in general is also reflective of shifting views towards the EU, but she relies on the premise that the domestic environment, such as the military coups, political party alliances and labor regulations, influences the ways in which trade unions perceive the EU. Consequently, the unions appeal to the EU when they are not satisfied with the domestic politics.

In order to examine the perceptions of the labor unions on EU membership and the reforms it necessitates, scholars tend to look at the cases of Türk-İş (Türkiye İşçi Sendikaları Konfederasyonu, Confederation of Turkish Trade Unions), DİSK (Devrimci Isş̧i Sendikaları Konfederasyonu, Confederation of Revolutionary Trade Unions), KESK (Confederation of Public Laborer's Unions) and Hak-İşs (Hak İşçi Sendikaları Konfederasyonu, Confederation of JusticeSeekers' Trade Union). These Unions are all members of the European Trade Union Confederation. Alemdar describes TÜRK-İŞ as a state-centric labor union, showing that Türk-İş took an openly anti-EU stance after 2000 but has softened its position since 2005, as membership negations began. TÜRK-IŞ̧'s position vis-à-vis the EU is very well explicated by Yıldırım Koç, who is one of the advocates of the syndicate:

The European Union's demands for Turkey are in opposition to the Turkish Republic's unitary state system and its independence. Abiding by these demands would tear our country apart and divide it, creating a new Yugoslavia. Turkey is not going to solve its problems through the EU. Turkey is not going to be stronger because of the EU. Turkey is going to solve its problems despite the EU, and it will be stronger. Turkey's admittance to the EU is dependent on this strength. ${ }^{50}$

It is important to note that Koç's argument is similar to the political parties' concerns over territorial integrity as well as the unity of the Republic. While TÜRK-ISS did not necessarily reflect the structure of its counterparts in the EU, DISK, which is considered a supporter of the left wing, reformulated itself in the 1990s in line with the European trade unions. ${ }^{51}$ Consequently, DISK has been adamant in pressuring the government and lobbying to harmonize Turkish labor regulations with those of the EU. ${ }^{52}$

Hak-İş, on the other hand, presents a different dynamic in the sense that Hak-İş’ attitude towards the EU has been intricately linked with the organization's liaisons with the government. When the government was pursuing the EU, the appeal of the EU was strong, and vice-versa. ${ }^{53}$ In December 1999, Hak-İş declared its stance towards the EU as follows:

A major challenge to integration with Europe is Turkey's Muslim population. Turkey, because of its historical, moral, philosophical, religious and national characteristics, is not Western. 'Westernization' comes as a betrayal and alienation to Turkish culture ... if membership in the EU is pushed, this would mean a total surrender [to Western values]. On the other hand, Turkey's application for EU membership means a heavy legal burden for the Constitution and other laws, and constitutes a threat to the state's sovereignty and the nation's unity...the fact that the government and the opposition parties are silent about this raises questions. ${ }^{54}$

However, as the Islamist political parties modified their perceptions of the EU and the notion of Westernization, Hak-İş also followed the same discourse, in line with the AKP. 
During and after the Gezi movement, the labor unions generated different perspectives. The majority of the Unions became critical Europeanists. Major trade unions such as DISK and KESK mobilized their mass organizations through the declaration of two general strikes during the protests in June 2013. Initially, the KESK called for a national 24 hour strike for June 5th. On June 4th, DISK, TMMOB (the Union of Chambers of Turkish Engineers and Architects) and TTB (The Turkish Medical Association) declared their support for the strike on the 5th of June. This strike took place with a significant participation from the public sector. It is estimated that between 400,000 and 500,000 workers participated in the strike throughout the country. ${ }^{55}$ Although Hak-İş and large parts of TÜRK-IŞ did not support the uprising, some platforms within TÜRK-IŞ joined the strike to declare their support for the protesters against the brutality of state security forces.

\section{Media}

First and foremost, it should be noted that similarly to the literature on trade unions, the literature on the role of the media in the process of modernization and Europeanization of Turkey is very limited. Nevertheless, scholars have studied the nature of the Turkish media, which can be used to indicate certain trends. During the period between 1982 and 1993, it is possible to observe a proliferation in media outlets, which was a result of non-media-related capital in the sector altering the structure of the media to resemble industrial enterprises. ${ }^{56}$ The technological developments during this period contributed to the establishment of numerous television and radio channels, both local and national. As the intensity of competition increased in tandem with the rise of capitalist ideology, media enterprises began to focus more on sales. In correlation with the increased competition, this period was marked by, among other things, the rise of monopolies in the sector, which in return created support for the government and politicians due to the growing need for "incentives, credits, and public announcements." 57

The Turkish media could be categorized as a part of the Mediterranean model. In this model, the journalists "take sides as members of the political and literary elites." The Mediterranean, or Polarized Pluralist Model, is characterized by an elite-oriented press with relatively small circulation and a corresponding centrality of electronic media. Freedom of the press and the development of commercial media industries generally came late; newspapers have often been economically marginal and in need of subsidy. Political parallelism tends to be high; the press is marked by a strong focus on political life and external pluralism, and the tradition of commentaryoriented or advocacy journalism persists more strongly than in other parts of Europe. Instrumentalization of the media by the government, by political parties and by industrialists with political ties is common. Professionalization of journalism is not strongly developed as in the other models. Journalism is not strongly differentiated from political activism and the autonomy of journalism is often limited. ${ }^{58}$

Turkish journalists have also been swinging between Euro-supportiveness and Euroskepticism while framing the EU beyond traditional institutional news coverage, like "Turkey must fulfill its EU requirements by..." or "the EU must fulfill its promises..." ${ }^{59}$ While Arsan depicts the problematic nature of journalists situated in Brussels, it is also necessary to examine the nature of domestic sources of information. In terms of the domestic television channels, Gencel Bek suggests that Turkish media has also gone through a "tabloidization process." As a part of her research, she analyzes the state-owned TRT (Türkiye Radyo ve Televizyon Kurumu, Turkish Radio and Television Corporation), and characterizes the quality of the news as follows:

In general, the reports are quite bland accounts of cabinet meetings. There is no setting of context, interpretation, discussion or criticism. TRT just reports that such and such politicians met, in a formulaic way. The news gives no other information such as who else talked in the meeting, who said what, what the main aim of the meeting was, etc... What TRT does achieve, however, is full coverage of all the national ceremonies, reminding the public of national history from the perspective of the official memory. One could call TRT news the "news of the nation-state. ${ }^{60}$ 
The above-mentioned argument is partly a result of the mentality followed by RTÜK (Radyo Televizyon Üst Kurulu, Radio and Television Supreme Council), which is a public legal entity that monitors television channels. On that issue Gencel Bek criticizes the operations of the RTÜK for being in favor of the state. She argues:

\begin{abstract}
The peculiar characteristics of broadcasting regulation also have an effect on content: the RTÜK controls content to a far greater extent than media structure, concentration, increasing market mechanisms, etc. Content control and subsequent penalties are mainly directed towards the channels 'which are against the state.' Protecting the state takes precedence over the citizen's right to information. ${ }^{61}$
\end{abstract}

Even though Arsan and Gencel Bek examine different aspects of the Turkish media, it is possible to infer a common theme, which is that the news media - both journalists in Brussels and the TRTfilter the news before it reaches the public. In that sense, the lack of professional and extensive media coverage from Brussels and the domination of the public service channel by nationalist events indicate that the citizen's right to information about the EU and the process of Europeanization has been overshadowed by political and social interests. Moreover, media coverage depends highly on the relations of media ventures with the government in particular, and with the political parties in general.

The media has been shifting between Euro-scepticism and pro-Europeanness. The EU has always been a practical source of legitimacy for the media in Turkey. Cumhuriyet and Sözcü, for instance, are two Kemalist daily newspapers with Euro-skeptic coverage prior to the Gezi movement. Both changed their discourses on the EU in parallel with that of the Republican People's Party. Both papers have become more pro-European during and after the Gezi movement. ${ }^{62}$ Another very interesting newspaper, which is likely to instrumentalize European integration for its own use, is Daily Zaman. It is publicly known that Zaman belongs to the Gülen community, which was an ally of the ruling party AKP. Recenty, the AKP rule cut off its alliance with the Gülen community. The divide between the party and the community became visible when Prime Minister Erdogan publicly declared in November 2013 that they would ban preparatory schools (dershane in Turkish), specialized education centers that help prepare students for high school and university entrance examinations. The Gülen community has hundreds of prep schools all around the country, where teachers affiliated with the mission of the community indoctrinate students with a kind of moderate Islam while preparing them for university and high school exams. Interestingly, Daily Zaman used Chapter 22 (Regional Policy) to spread its message out to its readers, saying that "the government plan to close down Turkey's prep schools will widen the educational gap created by social and economic inequality and regional disparities in Turkey, and it may endanger the implementation of the recently opened Chapter 22 in Turkey's European Union accession process. $" 63$

\title{
Conclusion: The Future of the EU Debate in Turkey
}

The analysis developed in this paper points to the relevance of the discursive interaction between the European internal debate and the Turkish debate on the EU. ${ }^{64}$ The article has shown that similar frames have been developed in the civil society debate in the EU and in Turkey. The fact that these are (partly) overlapping is evidence in itself of the ideational exchange between the two sides. Such exchange is both subterranean, channeled through a myriad of people-to-people micro-practices that create a de facto link between EU civil society and its Turkish counterpart, and explicit and public as reported in the media, in the conventional political debates or in the fora of elites.

In this regard, a particularly significant case study has been provided by the Occupygezi movement and its role in transforming part of the Turkish public debate on Europe. The harsh responses of the EU to the brutal acts of the Turkish state have contributed, perhaps unintentionally, to a radical turn in the mindsets of the secular groups, who were previously Euro-skeptic. After the events, these groups have become more pro-European than the supporters of the AKP rule. In other words, some of the Turkish civil society actors and private individuals started to critically embrace 
the European values by underlining their critical Europeanism. This kind of transformation was explained in the article through the ideological and political divides becoming sharper in the business associations, labor unions and the media. This confirms once again that the transformation of Turkish civil society is deeply intermingled with the European integration process. Sometimes it follows a linear trajectory, other times it may follow unexpected paths.

It is evident that the continuation of the democratization process in Turkey and the development of a civil society, both in Turkey itself and in its relation with the European counterparts, depend upon the path the EU is likely to take in the foreseeable future. One could also easily argue that Turkey's EU bid strongly shapes the internal discussions within the EU concerning the identity of the Union. It is comprehensible that the Turkish democratization process can be expected to persist alongside a liberal, political and post-civilizational project of Europe that would be ready to welcome Turkey, whereas a culturally and religiously defined Europe would possibly abstain from welcoming Turkey and would thus certainly interrupt the democratization process. Turkey's democracy is strongly linked to the ways in which the EU is being constructed and reconstructed. There are at least two definitions of Europe and the European Union. The first defines Europeanness as a static, retrospective, holistic, essentialist and culturally prescribed entity. The latter emphasizes the understanding of 'Europe' as a fluid, ongoing, dynamic, prospective, syncretic and nonessentialist process of becoming. While the first definition highlights a cultural project, the latter definition welcomes a political project embracing cultural and religious differences, including Islam. In the article, it was argued that the Occupygezi movement triggered the existence of a group of critical Europeanists in different sectors such as business associations, labour unions and the media, who begun to underline the importance of European values as well as a social Europe in opposition to the Europe of markets. What is embraced by the critical Europeanists is a more political Europe that is needed to counter the apolitical and elite-driven Europe that we have known so far. Several years passed after the Gezi movement, but still the legacy of the movement continues in different ways. The latest manifestation of this legacy was revealed through the speeches of the President Erdoğan and Kemal Kiliçdaroğlu, the leader of the oppositional political party, CHP, in the aftermath of the failed military coup which took place on 15 July 2016. In the immediate aftermath of the failed coup the President explicitly expressed his anger against his opponents including the Gezi protesters ${ }^{65}$ while Kilicdaroglu praised the Gezi spirit in his speech delivered on 24 July 2016 in during a very crowded public rally organized in Taksim square where the gezi movement took place three years ago. ${ }^{66}$

Public support for the EU prior to the @Occupygezi movement dropped down to 34 percent primarily due to the Euro-skeptic political discourse of the Turkish government as well as due to the growing impact of the global financial crisis on the EU countries, especially on the next door neighbor Greece. However, there appeared a sharp increase in the public support for Turkey's membership to the EU following the Gezi movement reaching up to 61 percent in 2015. The main driving force behind this support was the increasing longing of the majority of the Turkish society for democracy, accountability, transparency, freedom of speech, and the rule of law, the values of which the EU was strongly believed to have. Recently, the public support for the EU has become even higher, reaching 75 percent due to the probability of the EU liberalizing the visa-regime vis-àvis Turkey. ${ }^{67}$ The right to travel without any visa restrictions has always been the main source of inspiration for the Turkish public to generate a stronger European identity. However, one needs to scrutinize further to understand the motivations of the Turkish citizens in becoming strongly proEuropean. The data gathered by the IKV in May 2016 show that the AKP electorate has also become pro-European during the intensification of the debates on visa liberalization, while the critical Europeanists and pro-Europeanists seem to be less inspired by these talks since many of them were reportedly disturbed by the content of the refugee deal signed between Turkey and the EU in March 2016. Many critical Europeanists have blamed the EU leaders as well as the EU Commission for not having shown any reaction to President Erdoğan's authoritarian moves towards 
the freedom of speech, academics and journalists as well as several other oppositional voices in the country criticizing his political maneuvers to control power.

\section{Bibliography}

Adaman, Fikret, Ayşe Buğra, and Ahmet İnsel, "Societal Context of Labor Union Strategy: The Case of Turkey," Labor Studies Journal. Vol. 20, No. 10 (2008), pp. 168-188.

Kaya, Ayhan and Raffaele Marchetti (2014). "Europeanization, Framing Competition, and Civil Society in the EU and Turkey," in Senem Aydin-Düzgit, Daniela Huber, Meltem Müftüler Bac, Fuat Keman, Jan tasci and Nathalie Tocci (eds.), Global Turkey in Europe II: Energy, Migration, Civil Society and Citizenship Issues in Turkey-EU Relations, Roma: Edizioni Nuova Cultura: 145-196.

Alemdar, Zeynep. "Turkish Trade Unions and the European Boomerang", European Journal of Turkish Studies, No. 9. Online since 08 December 2009, URL:/index3774.html.

Arsan, Esra. Avrupa Birliği ve Gazetecilik: Brüksel'den Bildirenlerin Gözünden Avrupalılık (EU and Journalism: Europeanness from the Perspective of those reporting from Brussels), Istanbul, Ütopya Yayınevi, 2007.

Atan, Serap. "Europeanization of Turkish Peak Business Organizations and Turkey-EU Relations," in Mehment Uğur and Nergis Canefe (eds.). Turkey and European Union integration: accession prospects and issues, London, Routledge, 2004, pp. 100-121.

Badiou, Alain. The Rebirth of History: Times of Riots and Uprisings, London, Verso, 2012. Mehmet Bardakçı, "Turkish Parties' Positions towards the EU: Between Europhilia and Europhobia," Romanian Journal of European Affairs, Vol. 10, No. 4 (2010), pp. 26-41.

Calhoun, Craig. "Occupy Wall Street in Perspective," British Journal of Sociology, 64, No. 1 (2013), pp. 26-38.

Casanova, José. "The Long, Difficult, and Tortuous Journey of Turkey into Europe and the Dilemmas of European Civilization," Constellations, Vol. 13, No. 2 (2006), pp. 234-247.

Council of the European Union. EU Strategic Framework and Action Plan on Human Rights and Democracy, Luxembourg (11855/12/2012).

Della Porta, Donatella. "Critical Trust: Social Movements and Democracy in Times of Crisis," Cambio, Anno II, Numero 4 (December 2012), pp. 33-44.

Della Porta, Donatella and Manuela Caiani, Social Movements and Europeization, Oxford, Oxford University Press, 2009.

Doğan, Erhan. “Sendikalar ve Türkiye'nin Avrupa Birliği Seyahati” (Trade Unions and Turkey’s EU Journey), Akdeniz Universtiy IIBF Journal, 6 (2003), pp. 19-43.

Economic and Social Committee. The Role and Contribution of Civil Society Organizations in the Building of Europe, Brussels, CES 851/1999.

European Commission. European Governance: A White Paper, Brussels, COM (2001).

Gencel Bek, Mine. "Tabloidization of the Turkish Media: An Analysis of Television News in Turkey," European Journal of Communication. Vol. 19, No. 3 (2004), pp. 371-386.

Hardt, Michael and Antonio Negri, Declaration, New York, Melanie Jackson Agency, 2012, http://antonionegriinenglish.files.wordpress.com/2012/05/93152857-hardt-negri-declaration2012.pdf 
Harvey, David. Rebel Cities: From the Right to the City to the Urban Revolution, London, Verso, 2012.

Holston, James. Insurgent Citizenship, Princeton, Princeton University Press, 2008.

Kalaycioğlu, Ersin. "State and Civil Society in Turkey: Democracy, Development and Protest," in Amyn B. Sajoo (ed.), Civil Society in Muslim World: Contemporary Perspectives, London, New York, I.B. Tauris Publishers, 2002, pp. 247-272.

Kaya, Ayhan and Turgut Tarhanlı (eds.), Türkiye'de Çoğunluk ve Azınlık Politikaları: AB Sürecinde Yurttaşlık Tartışmaları (Majority and Minority Policies in Turkey: Citizenship Debates on the way to the EU), Istanbul, TESEV Publications, 2005.

Kaya, Ayhan. "Islamization of Turkey under the AKP Rule," Empowering Family, Faith and Charity," South European Society and Politics (2015), DOI: 10.1080/13608746.2014.979031.

Kaya, Ayhan. Europeanization and Tolerance in Turkey: The Myth of Toleration, London, Palgrave, 2013.

Keyman, Fuat and Ahmet İçduygu. "Globalization, Civil Society and Citizenship in Turkey: Actors, Boundaries and Discourses”, Citizenship Studies, Vol. 7, No. 2 (2003), pp. 219-234.

Konda Public Survey. "Gezi Parkı Araştırması," (6-7 June 2013), http://t24.com.tr/files/GeziPark\%C4\%B1Final.pdf.

Kubicek, Paul. "Turkish Accession to the European Union: Challenges and Opportunities," World Affairs, 168, 2 (2005), pp. 67-78.

Lefebvre, Henri. "The Right to the City," English translation of the 1968 text in Eleonore Koffman and Elizabeth Lebas, Writings on Cities, London, Blackwell, 1996.

Seufert, Guenther. "Is the Fethullah Gülen Movement overstretching itself? A Turkish religious community as a national and international player," SWP Working Paper 2, Berlin (2014), available online at: http://www.swpberlin.org/fileadmin/contents/products/studien/2013_S23_srt.pdf

Öniş, Ziya. "Turkish Modernization and Challenges for the New Europe," Perceptions (Autumn 2004), pp. 5-28.

Özbudun, Ergun and Serap Yazıcı. Democratization Reforms in Turkey, Istanbul, TESEV, 2004.

Sağnak, Mehmet. Medya-Politik: 1983-1993 Yılları Arasında Medya-Politikacı İlişkileri, Ankara, Eti Kitapları, 1996.

Saktanber, Ayşe and Gül Çorbacioğlu. "Veiling and Headscarf Skepticism in Turkey",Social Politics: International Studies in Gender, State \& Society, Vol. 15, No. 4 (2008), pp. 514-538.

Sitrin, Marina. "What does democracy look like?" The Nation (April 2012). http://www.thenation.com/article/166824/what-does-democracy-look.

Turam, Berna (ed.), Secular State and Religious Society: Two Forces in Play in Turkey, New York, Palgrave Macmillan, 2012.

Yankaya, Dilek. "The Europeanization of MÜSİAD: Political opportunism, Economic Europeanization, Islamic Euroscepticism", European Journal of Turkish Studies [Online], 9 (2009), Online since 08 Dec. 2009. URL : http://ejts.revues.org/index3696.html. 
Yıldırım, Engin, Suayyip Calış, and Abdurrahman Benli. "Turkish Labour Confederations and Turkey's Membership of the European Union," Economic and Industrial Democracy, No. 29 (2008), pp. 362-387.

${ }^{1}$ Ayhan Kaya and Raffaele Marchetti. "Europeanization, Framing Competition, and Civil Society in the EU and Turkey," in S. Aydin-Düzgit et al. Eds., Global Turkey in Europe II: Energy, Migration, Civil Society and Citizenship Issues in Turkey-EU Relations, Roma: Edizioni Nuova Cultura, 2014. pp. 145-196.

${ }^{2}$ Ayhan Kaya and Raffaele Marchetti. "Europeanization, Framing Competition, and Civil Society in the EU and Turkey."

${ }^{3}$ José Casanova, “The Long, Difficult, and Tortuous Journey of Turkey into Europe,” p. 245.

${ }^{4}$ Ergun Özbudun and Serap Yazıc1, Democratization Reforms in Turkey, Istanbul, TESEV, 2004. For further discussion on the impact of the European integration process on the state of minorities in Turkey, see Ayhan Kaya and Turgut Tarhanlı (eds.), Türkiye'de Çoğunluk ve Azınlı Politikaları: AB Sürecinde Yurttaşlık Tartışmaları (Majority and Minority Policies in Turkey: Citizenship Debates on the way to the EU), Istanbul, TESEV Publications, 2005.

${ }^{5}$ Ayhan Kaya, Europeanization and Tolerance in Turkey, London: Palgrave, 2013. Chapter 1.

${ }^{6}$ Ayhan Kaya, Europeanization and Tolerance in Turkey, Chapter 1.

${ }^{7}$ Ziya Öniş, “Turkish Modernization and Challenges for the New Europe," Perceptions (Autumn 2004), p. 12.

${ }^{8}$ For further discussion on the decision of the ECtHR see, Ayşe Saktanber and Gül Çorbacığlu, "Veiling and Headscarf Skepticism in Turkey".

9 German Marshall Fund, 'Transatlantic Trends Survey,', German Marshall Fund, 2010, http://trends.gmfus.org/transatlantic-trends/country-profiles/.

10 European Commission, "Eurobaromenter 2013," July 11, 2013, http://ec.europa.eu/public_opinion/archives/eb/eb79/eb79_en.htm.

${ }^{11}$ EU leaders including Angela Merkel heavily criticized Erdogan's AKP for being so intolerant to the peaceful civilian protests and threatened to cut off Turkey from the accession negotiation talks. See "Main opposition urges Merkel not to block Turkey's EU path," Hurriyet Daily News, June 22, 2013, http://www.hurriyetdailynews.com/main-opposition-urges-merkel-not-to-block-turkeys-

eupath.aspx?PageID=238\&NID=49191\&NewsCatID=338.

${ }^{12}$ See "World socialists discuss Gezi protests in Istanbul," Hurriyet Daily News, November 11, 2013), http://www.hurriyetdailynews.com/world-socialists-discuss-gezi-protests-in istanbul.aspx?PageID $=238 \& \mathrm{NID}=57727 \&$ NewsCatID $=338$.

${ }^{13}$ Alain Badiou, The Rebirth of History: Times of Riots and Uprisings, London, Verso, 2012.

${ }^{14}$ Slavoj Žižek, "The simple courage of decision: a leftist tribute to Thatcher," New Statesman, April 17, 2013, http://www.newstatesman.com/politics/politics/2013/04/simple-courage-decision-leftist-tribute-thatcher.

15 Michael Hardt and Antonio Negri, Declaration, New York, Melanie Jackson Agency, 2012, http://antonionegriinenglish.files.wordpress.com/2012/05/93152857-hardt-negri-declaration-2012.pdf.

${ }^{16}$ Ayhan Kaya (2015). "Islamization of Turkey under the AKP Rule," Empowering Family, Faith and Charity," South European Society and Politics, DOI: 10.1080/13608746.2014.979031.

17 Marina Sitrin, "What does democracy look like?," The Nation, April 2012, http://www.thenation.com/article/166824/what-does-democracy-look.

${ }^{18}$ Hrant Dink Street, Ceylan Özkol Street, Pınar Selek Square and Mustafa Sarı Street are some of those names used by the protestors to demonstrate their solidarity with those who had been exposed to the discrimination of the state machinery either in the past or during the demonstrations. Naming the fictional streets of squares after those persons, the protestors aimed to restore justice which was not secured by the state. Personal interview with one of the activists, Yigit Aksakoglu, Istanbul, September 16, 2013.

${ }^{19}$ Donatella Della Porta, "Critical Trust: Social Movements and Democracy in Times of Crisis," Cambio, Anno II, Numero 4, December 2012, p. 40.

${ }^{20}$ Donatella Della Porta, "Critical Trust,” p. 41.

${ }^{21}$ For further information on Zucotti Park see Craig Calhoun, "Occupy Wall Street in Perspective," British Journal of Sociology, Vol. 64, No. 1, March 2013, pp. 26-38. 
22 Konda Public Survey, “Gezi Parkı Araştırması,” June $\quad$ 6-7 2013 , http://t24.com.tr/files/GeziPark\%C4\%B1Final.pdf.

${ }^{23}$ James Holston, Insurgent Citizenship, Princeton, Princeton University Press, 2008.

${ }^{24}$ Henri Lefebvre, "The Right to the City," English translation of the 1968 text in Eleonore Koffman and Elizabeth Lebas, Writings on Cities, London, Blackwell, 1996, p. 158.

${ }^{25}$ Henri Lefebvre, “The Right to the City,” p. 158.

${ }^{26}$ David Harvey, Rebel Cities: From the Right to the City to the Urban Revolution, London, Verso, 2012, p. 4.

${ }^{27}$ Henri Lefebvre, "The Right to the City," p. 36.

${ }^{28}$ For a more detailed discussion on the interchangeable use of the terms Europeanization, modernization, secularization and Westernization see Ayhan Kaya, Europeanization and Tolerance in Turkey, Chapter 1.

${ }^{29}$ Ergun Özbudun and Serap Yazıc1, Democratization Reforms in Turkey, pp. 14-16.

30 Fuat Keyman and Ahmet İçduygu, “Globalization, Civil Society and Citizenship in Turkey,” pp. 222-226.

${ }^{31}$ Paul Kubicek, "Turkish Accession to the European Union: Challenges and Opportunities," World Affairs, Vol. 168, No. 2, 2005, p. 762.

${ }^{32}$ Fuat Keyman and Ahmet İçduygu, "Globalization, Civil Society and Citizenship in Turkey,” p. 222.

33 Ersin Kalaycioğlu, "State and Civil Society in Turkey: Democracy, Development and Protest," in Amyn B. Sajoo (ed.), Civil Society in the Muslim World: Contemporary Perspectives, London and New York, I.B. Tauris Publishers, 2002, pp. 250-252.

${ }^{34}$ Ersin Kalaycıŏlu, "State and Civil Society in Turkey," p. 258.

${ }^{35}$ Ersin Kalaycıŏlu, "State and Civil Society in Turkey," p. 260.

36 Serap Atan, "Europeanization of Turkish Peak Business Organizations and Turkey-EU Relations," in Mehment Uğur and Nergis Canefe (eds.), Turkey and European Union Integration: Accession Prospects and Issues, London, Routledge, 2004, p. 109.

${ }^{37}$ Serap Atan, "Europeanization of Turkish Peak Business Organizations and Turkey-EU Relations,” p. 107.

${ }^{38}$ Follow-up reports have been published in 1999 and 2001. For complete texts of these reports please consult: http://www.tusiad.us/main_page.cfm?TYPE_ID=12.

39 Serap Atan, "Europeanization of Turkish Peak Business Organizations and Turkey-EU Relations,” p. 111.

${ }^{40}$ Serap Atan, "Europeanization of Turkish Peak Business Organizations and Turkey-EU Relations," p. 112.

41 Dilek Yankaya, "The Europeanization of MÜSİAD: Political opportunism, Economic Europeanization, Islamic Euroscepticism," European Journal of Turkish Studies, No. 9, 2009, December 8, 2009, http://ejts.revues.org/index3696.html.

${ }^{42}$ The political and societal alliance between the AKP and the Gülen movement deserves to be scrutinized. Since going into exile in the United States in 1999, Fethullah Gülen has favored the idea that the state should be transformed by an Islamist party to make Islam the dominant societal force. Gülen also emphasized that it was essential to train an elite with the intellectual capacity to govern the state and survive in the face of Western hegemony. He was also a firm believer in the idea that a transition of power could only be achieved with popular support in elections, which could only be acquired through rightfully responding to the constituents' claims and expectations. Before allying with the AKP, the Gülen movement did not participate in the popular debates regarding the Islamization of Turkish society, the headscarf issue, or the Imam Hatip schools for the training of preachers. This absence meant that secular circles ceased to regard the Gülen movement as a threat to their Europeanized lifestyles until the late 1990s. ${ }^{42}$ Gülen's convictions were also largely consistent with the Turkish state's cultural and educational policies implemented in the aftermath of the 1980 military coup d'état. Over the course of time, aligning themselves with the state ideology, Gülen supporters represented a combination of national-religious sentiments and socio-moral conservatism, and were committed to the creation of a strong state, while simultaneously opposing the organization of political Islam. Mushrooming of the Gülen schools inside and outside Turkey, establishing various foundation universities in different parts of the country, founding several different civil society organizations and business associations, such as the Foundation of Journalists and Writers (Gazeteciler ve Yazarlar Vakfi) and the Turkish Confederation of Businessmen and Industrialists (TUSKON), organizing Turkish Language Olympics, launching charity-support networks, training its own professional intellectuals, aligning with the AKP, and integrating itself into various ministerial and bureaucratic ranks of the state, the Gülen movement has in a way developed a kind of statist stance. Eventually, the latest coup attempt which took place on 15 July 2016 revealed the wide-spread power of the Gülen movement within the army. For further detail see Guenther Seufert, "Is the Fethullah Gülen Movement overstretching itself? A Turkish religious community as a national and international player," SWP Working Paper 2, Berlin (2014), available online at: http://www.swp-berlin.org/fileadmin/contents/products/studien/2013 S23 srt.pdf; and Berna Turam (ed.), Secular State and Religious Society: Two Forces in Play in Turkey, New York, Palgrave Macmillan, 2012. 
${ }^{43}$ See http://www.ikv.org.tr and http://www.tesev.org.tr.

${ }^{44}$ For a list of some of these organizations see the website of the World Movement for Democracy, http://www.wmd.org/resources/whats-being-done/human-rights-democracy-turkey/list-turkish-ngos-workinghuman-rights-and-

45 “Gezi Park Statement from TÜSİAD” http://www.hurriyet.com.tr/ekonomi/23414830.asp retrieved on 20 June 2016.

46 "The Businessmen that is close to Gülen Anxious" http://www.wsj.com.tr/article/SB10001424052702303562904579223742211718068.html retrieved on 18 June 2016.

${ }^{47}$ Engin Yıldırım, Suayyip Calış and Abdurrahman Benli, “Turkish Labour Confederations and Turkey's Membership of the European Union," Economic and Industrial Democracy, No. 29, August 2008, p. 363.

${ }^{48}$ Fikret Adaman, Ayșe Buğra and Ahmet İnsel, "Societal Context of Labor Union Strategy: The Case of Turkey,” Labor Studies Journal, Vol. 20, No. 10, February 2008, pp. 8, 168-188.

${ }^{49}$ Zeynep Alemdar, "Turkish Trade Unions and the European Boomerang," European Journal of Turkish Studies, No. 9, December 8, 2009, index3774.html, p. 3.

${ }^{50}$ Cited in Zeynep Alemdar, "Turkish Trade Unions and the European Boomerang," p. 9.

${ }^{51}$ Zeynep Alemdar, "Turkish Trade Unions and the European Boomerang," p. 15.

${ }^{52}$ Erhan Doğan, "Sendikalar ve Türkiye'nin Avrupa Birliği Seyahati”" (Trade Unions and Turkey’s EU Journey), Akdeniz University IIBF Journal, No. 6, 2003, pp. 19-43.

${ }^{53}$ Zeynep Alemdar, "Turkish Trade Unions and the European Boomerang," p. 19.

${ }^{54}$ Cited in Zeynep Alemdar, "Turkish Trade Unions and the European Boomerang," p. 20.

${ }^{55}$ International Communist Current. (2013, June 25). "Turkey: The cure for state terror isn't democracy". Retrieved 20 June 2016 from http://en.internationalism.org/icconline/201306/8371/turkeycure-state-terror-isntdemocracy

${ }^{56}$ Mehmet Sağnak, Medya-Politik: 1983-1993 Yılları Arasında Medya-Politikacı İlişkileri, Ankara, Eti Kitapları, 1996, pp. 55-56.

${ }^{57}$ Mehmet Sağnak, Medya-Politik, p. 51.

58 Esra Arsan, Avrupa Birliği ve Gazetecilik: Brüksel'den Bildirenlerin Gözünden Avrupalllk (EU and Journalism: Europeanness from the Perspective of those reporting from Brussels), Istanbul, Ütopya Yayınevi, 2007.

${ }^{59}$ Esra Arsan, Avrupa Birliği ve Gazetecilik, p. 72.

${ }^{60}$ Mine Gencel Bek, "Tabloidization of the Turkish Media: An Analysis of Television News in Turkey," European Journal of Communication. Vol. 19, No. 3, 2004, p. 378.

${ }^{61}$ Mine Gencel Bek, "Tabloidization of the Turkish Media," p. 383.

${ }^{62}$ See http://sozcu.com.tr and http://www.cumhuriyet.com.tr.

${ }^{63}$ See Nesibe Hicret Soy, "Ban on prep schools deals blow to EU's Chapter 22," Today's Zaman, November 24, 2013, http://www.todayszaman.com/news-332130-ban-on-prep-schools-deals-blow-to-eus-chapter-22.html.

${ }^{64}$ Ayhan Kaya and Raffaele Marchetti. "Europeanization, Framing Competition..."

${ }^{65}$ See Peter Westmacott, "The failed coup casts a shadow over Turkey," Financial Times, 18 July 2016, available at http://www.ft.com/cms/s/0/81a6d7fa-4c35-11e6-88c5-db83e98a590a.html\#axzz4FXu1xjOS

${ }^{66}$ See "CHP leader announces 'Taksim Declaration' after failed coup attempt," Hurriyet Daily News, 25 July 2016, available at http://www.hurriyetdailynews.com/chp-leader-announces-taksim-declaration-after-failedcoup-attempt-.aspx?pageID $=238 \& n I D=102040 \& N e w s C a t I D=338$

${ }^{67}$ According to a similar survey conducted by the IKV, Istanbul Development Association, in April 2015, public support for membership to the EU was 61 percent. For this comparison see the website of the IKV, http://web.ikv.org.tr/icerik_print.asp?id=1403 